Volume 6 Issue 2, September 2021:pp. 267-287 Copyright@ LamLaj. Faculty of Law, Lambung Mangkurat University, Banjarmasin,

South Kalimantan, Indonesia. ISSN: 2502-3136 | e-ISSN: 2502-3128.

Open Access at: http://lamlaj.ulm.ac.id/web/

\title{
COMMERCIAL BUSINESS DISPUTE SETTLEMENT THROUGH ONLINE NON-LITIGATION DISPUTE SETTLEMENT IN INDONESIA
}

\author{
Ayudia Nur Rifdah ${ }^{1}$, Mulyani Zulaeha ${ }^{2}$, Yulia Qamariyanti ${ }^{3}$ \\ Masters in Law at Lambung Mangkurat University \\ Jl. Brigadier General H. Hasan Basry Banjarmasin 70123 \\ Email:Ayudiarifdah@gmail.com \\ Faculty of Law, University of Lambung Mangkurat \\ Jl. Brigadier General H. Hasan Basry Banjarmasin 70123 \\ Email: mulyani.zulaeha@ulm.ac.id \\ Faculty of Law Lambung Mangkurat University \\ Jl. Brigjend H. Hasan Basry Banjarmasin 70123 \\ Email:yuliaqamariyanti@yahooo.com
}

Submitted : 24/04/2021 Reviewed: 20/09/2021 Accepted:29/09/2021

\begin{abstract}
The purpose of the research entitled Settlement of Commercial Business Disputes through Online Non-Litigation Dispute Resolution in Indonesia is to analyze the mechanism for resolving commercial business disputes through nonlitigation in the form of ODR in Indonesia and its legal consequences. The research method is in the form of normative legal research, which is a method that uses statutory regulations, which are then analyzed and drawn conclusions from general matters into a specific conclusion. The results of the research obtained are, First: that the legal basis that contains and states implicitly regarding matters relating to ODR is contained in Law Number 30 of 1999 concerning Arbitration and Alternative Dispute Resolution, namely, the contents of the legal regulations also do not provide much clarity. Details on how the conditions for ODR are carried out, the ODR mechanism, and other explanations. Second, the Inconsistency Norm that occurs in regulations relating to dispute resolution through non-litigation $O D R$, namely between several articles in the AAPS Law, there is a discrepancy or contradiction between the rules or articles that apply, so that the legal rules become vague and unclear. Where according to several articles of the AAPS Law it is stated that the Arbitration dispute resolution process must be written, while according to other articles of the AAPS Law it can be online. There is a legal ambiguity in the nonlitigation dispute resolution mechanism through ODR, so that the parties feel that there are no clear directions or instructions in resolving cases, this makes the process of non-litigation dispute resolution mechanisms through ODR not well directed, due
\end{abstract}


to disharmony or inconsistency the rule of law, so that the rule of law becomes vague, vague and unclear. The solution to these legal issues is that the government should make legal regulations that specifically regulate ODR or revise Law Number 30 of 1999 and add articles related to ODR. To the Government to provide websites and institutions that can specifically handle non-litigation dispute resolution through ODR to handle commercial business dispute resolution.

Keywords: Business Disputes; Non Litigation; ODR

DOI: 10.32801/lamlaj.v6i2.247

\section{INTRODUCTION}

Online dispute resolution in Indonesia is considered to be "faster, simpler, and less expensive" so that business people can resolve their disputes based on this principle. Online dispute resolution is also considered to balance the pace of development of the technology and information era, so that the application of online settlement is considered important in legal reform in Indonesia. ${ }^{1}$ In general, business disputes can be resolved in two ways, namely by litigation and non-litigation processes. The current digital era offers a creative and innovative solution by involving technology and the internet as supporting factors in resolving a dispute arising from a trading activity. Settlement of business disputes in the digital era can be via the internet which is then known as online dispute resolution, online mediation, and online arbitration. ${ }^{2}$

The free market system and free competition between countries have resulted in fastgrowing business transactions. With hundreds of thousands of business transactions every day, the intensity of business transactions both

\footnotetext{
1 Muhammad Azwar, "Prospek Penerapan Online Dispute Resolution Dalam Upaya Penyelesaian Sengketa Bisnis Di Indonesia," Media Iuris 2, no. 2 (2019): 5, http://dx.doi.org/10.20473/mi.v2i2.13912.

2 Rifkin Janet Katsh, Online Dispute Resolution: Resolving Conflict in Cyberspace (Bandung: Genta Publishing, 2016), 93
}

domestically and internationally is expected to increase every day, which will trigger an increase in the frequency of disputes. Various disputes arising from business activities or commercial activities are generally called business disputes or commercial disputes. ${ }^{3}$ Every business dispute that occurs must be resolved quickly.

The more and the extent of trading activities, the higher the occurrence of disputes, resulting in many disputes that must be resolved. Allowing trade/business disputes to be resolved late will result in inefficient economic development, decreased productivity, a barren business world, increased production costs and hampers the welfare and social progress of the workers. ${ }^{4}$ Conventionally, commercial dispute resolution is generally resolved through the courts (litigation).

ODR as Dispute Resolution has offered a new concept in dispute resolution on the internet, but also provides several possibilities. Daewon Choi in his writing entitled Online Dispute Resolution: Issues and Future Directions expressed his opinion as follows: "Some of these possibilities include not only detemporalization and depersonalization but also

\footnotetext{
${ }^{3}$ Eman Suparman, Pilihan Forum Arbitrase Dalam Sengketa Komersial Untuk Penegakan Keadilan (Jakarta: Tatanusa, 2004), 5.

${ }^{4}$ Ibid.
} 
dematerialization and deterritorialization of conflicts."

From this statement it is very clear that ODR offers a very wide scope of dispute or conflict resolution. Forms of disputes that are very difficult to resolve through a settlement system in the real world, through this ODR will be resolved properly. The forms of such disputes include data protection disputes, taxation in transactions, and defamation or invasion of privacy. In fact, the ODR model has begun to be practiced by several parties as evidenced by the presence of internet services that specifically provide services in terms of ODR. One thing that can be observed is a website from Australia known as www.adronline.com.au. In addition, there are also other sites, namely www.squaretrade.com.

There is one legal basis that contains and states implicitly related to Online Dispute Resolution, namely Article 4 of Law Number 30 of 1999 concerning Arbitration and Alternative Dispute Resolution: telex, telegram, facsimile, e-mail or in other forms of means of communication, must be accompanied by a note of receipt by the parties."

However, this regulation still does not have clear legal certainty regarding non-litigation ODR.

According to the author, the legal regulations have not provided much detailed clarity on how the conditions for implementing ODR, the ODR mechanism, and other explanations are. It should be realized that online dispute resolution is also still experiencing many obstacles and obstacles in Indonesia such as the absence of specific legal regulations related to ODR, uneven internet connections, there are still many concerns of Indone-

\footnotetext{
5 Budi Agus Riswandi, Hukum Cyberspace (Yogyakarta:
} Gita Nagari, 2006), 3. sian citizens who do not believe in the validity of soft-file documents, dispute resolution online still doesn't sound familiar to some Indonesian people, there are not many facilities and infrastructure that support online dispute resolution to make it easier for the community such as institutions or websites, etc.

According to the author, although there are regulations that implicitly regulate the settlement of commercial business disputes through non-litigation online dispute resolution, the mechanism is still unclear in detail, so that the legal rules become vague, vague and unclear, which also makes the parties involved does not have a strong legal basis and later the process of resolving commercial business disputes through non-litigation online dispute resolution will not be well directed.

Based on the description above, the author would like to further examine matters relating to how the legal certainty of non-litigation commercial business dispute resolution mechanisms through Online Dispute Resolution in Indonesia.

Based on the description of the background of the problem, the formulation of the problem is: What is the mechanism for resolving commercial business disputes through nonlitigation online dispute resolution in Indonesia? And what are the legal consequences of uncertainty regarding the mechanism for resolving commercial business disputes?

The objectives of this study are: to analyze the mechanism for resolving commercial business disputes through non-litigation online dispute resolution in Indonesia and to analyze the legal consequences of the uncertainty of the mechanism for resolving commercial business disputes through non-litigation online dispute resolution in Indonesia. 


\section{METHOD}

Types of research

This research uses normative legal research, the implementation of normative legal research is carried out by conducting an inventory of positive law, implementing legal principles and rules of legislation and legal doctrine, normative research is legal research that puts law as a system of norms.

Approach Method

This research uses two kinds of approaches, namely: Statue approach, This approach is carried out to examine all laws and regulations relating to legal problems that are being experienced or faced and Conceptual Approach. The Conceptual Approach, namely the absence of legal rules for the problems at hand, in building the concept must first move from the doctrines that develop in the science of law.

\section{Research Type}

The type of research used is doctrinal research, namely research that provides systematic exposure to regulations governing certain legal categories, analyzes relationships between articles, explains what is experiencing obstacles, and predicts data development.

\section{Source of Legal Material/Data}

The types of legal materials used are:

a. Primary legal materials, namely legal materials in the form of norms or basic rules of laws and regulations that have binding force and applicable laws and regulations in Indonesia, namely: Law Number 30 of 1999 concerning Arbitration and Alternative Dispute Resolution Article 4, Article 6 aragraph (2). Article 8, Article 9 paragraph (1), Article 24 paragraph (5), Article 31 paragraph (1), Article 36 paragraph (1), Article 36 paragraph (2), Article 50 paragraph (3), Article 59 paragraph (2), and Article 63;

b. Secondary legal materials, namely legal materials that provide an explanation of primary legal materials, such as scientific works of legal experts, research results, books, journal articles, internet articles, and other materials related to the subject matter;

c. Tertiary legal materials, namely legal materials that provide explanations for primary legal materials and secondary legal materials, namely the Legal Dictionary, Big Indonesian Dictionary.

Legal Material/Data Collection Techniques

Based on the approach used in this research, the technique of collecting legal materials used is document study. The legal materials collected are legal materials obtained from library research, written materials consisting of primary legal materials, secondary legal materials, and tertiary legal materials.

Legal/Data Material Analysis

The data analysis technique used by the researcher in this study uses deductive to inductive logic, namely the mindset to draw conclusions from general things to specific conclusions.

\section{ANALYSIS AND DISCUSSION \\ COMMERCIAL BUSINESS DIS- PUTE SETTLEMENT MECHANISM THROUGH NON LITIGATION ONLINE DISPUTE RESOLUTION IN INDONESIA} Legal Certainty on Regulations of Commercial Business Dispute Resolution Mechanisms through Non Litigation Online Dispute Resolution as an Alter- 


\section{native for Dispute Resolution in the In- donesian Legal System}

There is some debate regarding the ODR mechanism in handling a dispute. Some of these problems are in terms of the division of roles between human and non-human elements, the emotional factors of the disputing parties which are difficult to judge in terms of online methods, and problems with internet network connections.

Professor of the Faculty of Law, Parahyangan University, Bernadette M Waluyo, conveyed the need for a common understanding for all parties regarding the ODR. He explained that ODR can be understood as a means and a way of resolving disputes. In the context of facilities, ODR only plays a role in receiving consumer complaints or claims. Meanwhile, in the context of dispute resolution methods, ODR covers the complaint process to facilitate communication between consumers and business actors, whether involving third parties or not.

Bernadette said the implementation of ODR is a necessity so that the Indonesian legal system must be ready to face these changes. What's more, ODR through artificial intelligence technology can determine the verdict. Although, he doubts that artificial intelligence can replace the role of law enforcement.

"Artificial intelligence can make changes in the legal profession such as judges, lawyers or arbitrators who will be replaced by robots in making legal decisions like judges. Although it is undeniable that robots do not have a conscience and humanity that will be lost and cannot be possessed by robots," explained Bernadette, in the discussion "Digitalization and Consumer
Access to Justice in Indonesia", Wednesday $(16 / 6)$.

ODR has challenges because there are institutions that have the authority to settle disputes. For example, dispute resolution in the financial and trade sectors has different authorities. In fact, the current development of the digital economy has combined the two sectors.

The legal basis that contains and states implicitly regarding matters relating to Online Dispute Resolution, which is contained in Law Number 30 of 1999 concerning Arbitration and Alternative Dispute Resolution.

According to the researcher, the legal regulations also do not provide much detailed clarity on how the conditions for implementing ODR, the ODR mechanism, and other explanations are. It should be realized that online dispute resolution also still has many obstacles and obstacles in Indonesia, such as the absence of legal regulations specifically related to non-litigation ODR and not many facilities that support online dispute resolution to facilitate the public such as institutions or special websites.

Law Number 30 of 1999 concerning Arbitration and Alternative Dispute Resolution, in Article 4 Paragraph (3): In the event that it is agreed that the settlement of a dispute through arbitration occurs in the form of an exchange of letters, the sending of telex, telegram, facsimile, e-mail or other means other communications, must be accompanied by a note of acceptance by the parties, and Article 36 Paragraph (2): Verbal examination may be carried out if agreed by the parties or deemed necessary by the arbitrator or arbitral tribunal. 
Based on Article 4 paragraph (3) and Article 36 paragraph (2), it is implied that Indonesia supports non-litigation dispute resolution through online dispute resolution.

According to the author, the contents of the legal regulations have not provided much detailed clarity regarding how the conditions for the implementation of ODR, the ODR mechanism, and other explanations are. There should be legal certainty in the form of a tangible form of legislation regarding Non-litigation dispute resolution mechanisms through Online Dispute Resolution. The form of legal certainty in the form of written regulations made by an institution that has the authority, legal certainty is one of the principles in good governance. With this legal certainty, the community will get certainty about how the steps can be taken by the community in solving legal problems.

Several countries in the world have implemented an Online Dispute Resolution system. As a comparison, this study uses America and China, because both countries have advantages in their respective fields. The United States excels in technological advancement (HI-tech), while China excels in the level of trade.

\section{America's Online Dispute Resolution Model}

Dispute resolution through ODR is generally one of the options provided by ADR institutions. One of the arbitration institutions in America has provided online dispute resolution (ODR) services, namely the American Arbitration Association (hereinafter referred to as "AAA"). AAA was formed in 1926 under the Fed- eral Arbitration Act, the AAA has a specific purpose in assisting the implementation of arbitration as an "out-of-court solution" to resolve disputes. The mission of AAA is dedicated to effective, efficient and economical methods of dispute resolution through education, technology, and service-oriented solutions.

\section{Dispute Resolution Online Model in china}

Dispute resolution through ODR is organized by the China International Economic and Trade Arbitration Commission (CIETAC) based on its self-regulation, namely the CIETAC Online Arbitration Rules (CIETAC OAR). Cietac ODR Center is a special agency formed by CIETAC to serve online dispute resolution, developing a website that is used as a media for online dispute resolution.

\section{Legal Vague regarding Models and Con- cepts of Commercial Business Dispute Resolution Mechanisms through Non- Litigation Online Dispute Resolution in Indonesia}

Litigation is a term in law regarding the settlement of a dispute faced through the courts. The process involves the disclosure of information and evidence related to the dispute at trial in order to avoid unforeseen problems in the future. The dispute is resolved under the auspices of the judge. Article 22 of the 1945 Constitution states that the judicial system is under the authority of the Supreme Court and the judicial bodies below it. ${ }^{6}$

\footnotetext{
6 "Mengenal Litigasi: Mengenai Penyelesaian Sengketa Di Meja Hijau," DSLA, accessed February 19, 2021, https:/www.dslalawfirm.com/id/litigasi/.
} 
These judicial bodies include general courts, religious courts, state administrative courts, military courts and constitutional courts.

There are various types of dispute resolution through litigation.

Types of litigation cases such as: ${ }^{7}$

1. Regarding land acquisition

2. Banking

3. Civil disputes

4. Commercial business disputes

5. Corporate crime (fraud)

6. Settlement of false accusations or seizure of child custody (facilitated by the religious court).

From January to May 2008, the Supreme Court had 9,306 remaining cases from the remaining 20,314 cases in 2005, while from January to May 2008 there were 4,457 cases. $^{8}$

Based on these data, according to the author, the settlement of business disputes through official courts generally takes a long time and requires large costs due to the factors of the judicial system procedures which are very complex, convoluted and quite complicated. Even for a civil case it can take years to settle the dispute until the judge's decision is read out. Not only that, the decision that has come out of the court does not necessarily give satisfaction to the disputing parties so that they submit legal remedies such as appeals, cassation or judicial review.

According to the author, this makes the

7 Ibid.

8 "MA Memiliki Sisa Perkara Sebanyak 9.306," Mahkamah Agung Republik Indonesia, accessed February 11, 2021, https://www.mahkamahagung. go.id/. dispute resolution process very ineffective and efficient. Especially if the parties have their own activities so they only have limited time to participate in the dispute resolution process. In addition, the business world considers that dispute resolution in the business sector is less understood by judges when compared to those who are involved in the business world itself. Especially if the disputing parties are citizens of different countries, Indonesia on the one hand and foreign countries on the other. Which country's court is authorized to examine cases and considering that due to differences in jurisdiction, the decisions of foreign country courts cannot be executed in Indonesia.

With the development of increasingly sophisticated technology, it will result in arbitration which can also be carried out online via the internet, this is certainly very helpful for the parties, in terms of time and cost. Between countries, no passport or visa is required to enter other countries through a virtual world built over the internet. Thanks to the convenience of this information technology, the internet is not only used as a mere means of correspondence, but also for the implementation of dispute resolution through online non-litigation. $^{9}$

Models and Concepts of Non-Litigation Dispute Resolution Mechanisms through

\footnotetext{
9 Richard Hill and Ian Walden, "Electronic Commerce Can Be Defined as Commercial Activities Conducted through an Exchange of Information Generated, Stored, or Communicated by Electronical, Optical or Analogues Means, Including EDI, E-Mail, and so Forth" The Draft UNCITRAL Model Law for ," last modified 1996, http://openstorage.gunadarma. ac.id/idkf/idkf/aplikasi/hukum-dan-warfare/mastelregulasi-2B.doc14.
} 
Online Dispute Resolution in Indonesia:

\section{Online Negotiation Models and Con- cepts}

Online negotiation is an attempt to resolve disputes through online negotiation. This means that the parties are not required to meet and meet face-to-face, but the parties only need an internet connection to resolve disputes between the two. ${ }^{10}$

Online negotiations are part of the Online Dispute Resolution (ODR) or also known as APS Online. This Online Negotiation is categorized as ODR which does not involve a third party. ${ }^{11}$

According to Abdul Halim Barkatullah, online negotiations have an advantage over traditional negotiations in the form of simplicity. Where the parties are only required to have good faith and an internet connection in this online negotiation process. This simple process does not cost a lot, so it is more efficient than the direct negotiation process. ${ }^{12}$ This is because the parties are not required to travel in a meeting and face to face in a special place. In addition, this online negotiation also does not take much time, so it is more timesaving and efficient. Dispute resolution through online negotiation offers efficient, fast, and inexpensive dispute resolution. This is because the parties do not need to pay for meetings, sending letters, and duplicating documents. ${ }^{13}$

\footnotetext{
${ }^{10}$ Abdul Halim Barkatullah, Perlindungan Hukum Bagi Konsumen Dalam Transaksi E-Commerce Lintas Negara Di Indonesia (Yogyakarta: FH UII Press, 2009), 269.

${ }^{11}$ Ibid.

${ }^{12}$ Ibid.

${ }^{13}$ Ibid, 271
}

The simplicity of the online negotiation, according to Abdul Halim Barkatullah, is a drawback of the process, because there is no human touch in its implementation. So there is no observation of body language, meetings, and non-verbal perceptions as contained in direct negotiations. Where these things have an important role in understanding the position of each party. ${ }^{14}$

However, in the provisions of Law Number 30 of 1999 concerning Arbitration and Alternative Dispute Resolution, it is not known about ODR or online negotiations. So there is no strong legal basis in the use of online negotiations and ODR in e-commerce dispute resolution. Whereas online negotiations provide convenience in resolving disputes, which are not hindered by space, time limits, slow processes and high costs. It is cheaper and faster than direct or conventional negotiation. ${ }^{15}$

\section{Online Mediation Models and Concepts}

This type of ODR resolves disputes of little value. In accordance with the term, online mediation is not done face-to-face, but the dispute resolution is done online. This means that international business actors located in different countries can use online mediation tools to resolve disputes. One of the organizations that has online mediation dispute resolution services is Squaretrade, which is the result of the Uni-

\footnotetext{
${ }^{14}$ Ibid

${ }^{15}$ Gagah Satria Utama, "Online Dispute Resolution: A Revolution in Modern Law Practice," Business Law Review 1, no. 3 (2017): 5, https://law.uii.ac.id/wpcontent/uploads/2017/04/V-01-No-03-online-disputeresolution-a-revolution-in-modern-law-practicegagah-satria-utama.pdf.
} 
versity of Massachusetts research project. ${ }^{16}$

Online mediation is the same as offline mediation which usually in organizations goes through three stages. Opening session in which the parties, legal counsel, mediator, and possibly an expert or psychologist are present. In this session, the parties present their views, facts and legal issues where the mediator summarizes the problems faced by the parties. ${ }^{17}$

The other sessions are the same as described in the offline mediation process, the mediator discusses privately with each party online. This session is also known as the "Engine Room" of the entire procedure that must be passed. ${ }^{18}$ Next, the closing session where the parties meet again and verify the agreement that has been reached or at least there are results that have been achieved. The difference between online mediation and offline mediation is that in online mediation, the real world is replaced by the virtual world or cyberspace. ${ }^{19}$

Online Arbitration Models and Concepts

\footnotetext{
${ }^{16}$ Adel Candra, "Penyelesaian Sengketa Transaksi Elektronik Melalui Online Dispute Resolution (ODR) Kaitan Dengan UU Informasi Dan Transaksi Elektronik," Jurnal Ilmu Komputer 10, no. 2 (n.d.): 80-89, https://digilib.esaunggul.ac.id/public/UEUJournal-3653-adel-chandra.pdf.

${ }^{17}$ Bernadheta Aurelia Oktavira, "Perbedaan Mediator, Arbiter, Dan Konsiliator," Hukum Online, last modified 2019, accessed November 22, 2020, https://www.hukumonline.com/klinik/detail/ulasan/ $1 \mathrm{t} 5 \mathrm{dd} 65 \mathrm{ff} 35 \mathrm{fc} 6 \mathrm{f} /$ perbedaan-mediator--arbiter--dankonsiliator/.

${ }^{18}$ Kania Rahma Nureda, "Penyelesaian Sengketa Secara Online Di Indonesia," Hukum Online, last modified 2017, accessed November 22, 2020, https://www. hukumonline.com/berita/baca/lt593793b7764b1/ penyelesaian-sengketa-secara-online-di-indonesiaoleh--kania-rahma-nureda.

${ }^{19} \mathrm{Ibid}$.
}

Efforts to resolve online arbitration disputes have begun to be recognized and implemented in developed countries such as America, Britain, Canada and several countries in Europe. This dispute resolution method is very interesting because it is done online, making it easier for the parties to resolve disputes wherever they are without being hindered by time and place. ${ }^{20}$ In Indonesia, online arbitration is a new thing and has not been regulated in a special regulation. Regulations regarding arbitration in Indonesia are contained in Law Number 30 of 1999. However, in this law there is no regulation regarding online arbitration. Online arbitration itself is almost the same as conventional arbitration, the difference is in online arbitration the case registration process, arbitrator selection, decision making, document submission, arbitrator deliberation, and notification of a decision is made online. ${ }^{21}$ In addition, the discussion in online arbitration focuses on regulating the validity of arbitration agreements made online, online arbitration procedures, and online arbitration award issues. The importance of discussing Internet regulations is about the fact that the Internet is global and crosses national borders. ${ }^{22}$

In general, dispute resolution using the online arbitration method also involves a third party, namely an arbitrator who is neutral as a decision maker assisted by a fourth party, namely technology and the internet as a facilitator in the dispute reso-

\footnotetext{
${ }^{20}$ Paustinus Siburian, Arbitrase Online: Alternatif Penyelesaian Sengketa Perdagangan Secara Elektronik (Jakarta: Djambatan, 2004), 192-193

${ }^{21}$ Ibid. hlm.12

${ }^{22}$ Ibid.
} 
lution process of the parties. ${ }^{23}$

According to the author, there is a legal ambiguity regarding legal regulations regarding non-litigation dispute resolution mechanisms through ODR, so that the parties feel that there are no clear directions or instructions in resolving cases.

\section{Inconsistency of Regulations regard- ing Settlement of Commercial Business Disputes through Non-Litigation Online Dispute Resolution}

Consistency comes from the Latin word con-sistere which means to stand together. If interpreted the word consistent has the meaning of conformity, harmony, or has a logical relationship. Regarding the change of the adjective consistent into a noun, it is referred to as consistency, which means conformity, harmony, a state that has a logical relationship. The word consistency in the Big Indonesian Dictionary is determination and stability in action. While the word inconsistency is contradictory, contradictory, not appropriate. ${ }^{24}$ So legal inconsistency is the existence of a discrepancy or contradiction between the applicable legal rules, so that the legal rules become vague. ${ }^{25}$

Inconsistencies in regulations can result in public confusion in understanding these regulations. This confusion in society results in the non-optimal legislation in solving a problem that occurs. Inconsistency can also affect the legal balance that lives in the midst of society because of the dif-

\footnotetext{
23 Ibid.

${ }^{24}$ Pusat Bahasa Departemen Pendidikan Nasional, Kamus Bahasa Indonesia (Jakarta: Departemen Pendidikan Nasional, 2008), 556

25 Ibid.
}

ferent interpretations of judges on inconsistent laws and regulations. ${ }^{26}$

Inconsistency Norm (inconsistent legal norms) that occur in regulations relating to dispute resolution through non-litigation Online Dispute Resolution, namely between several articles in Law Number 30 of 1999 concerning Arbitration and Alternative Dispute Resolution, namely the existence of inconsistencies or contradictions between the rules/articles of law that apply, so that the rule of law becomes vague and unclear. That is, according to several articles of Law Number 30 of 1999 concerning Arbitration and Alternative Dispute Resolution, it is stated that the Arbitration dispute resolution process must be written, while according to other articles of Law Number 30 of 1999 concerning Arbitration and Alternative Dispute Resolution, it can be done online, according to the researcher. This makes the process of nonlitigation dispute resolution mechanisms through Online Dispute Resolution chaotic and disorganized, due to disharmony or inconsistency of legal regulations, so that the legal rules become vague, vague and unclear.

The results of the analysis related to disharmony or inconsistency norms that occur in regulations relating to dispute resolution through non-litigation Online Dispute Resolution in Indonesia, namely: (In this case the researcher will compare several articles in Law Number 30 of 1999 concerning Arbitration and Alternative

\footnotetext{
${ }^{26}$ Dhaniswara K. Harjono, "Pengaruh Sistem Hukum Common Law Terhadap Hukum Investasi Dan Pembiayaan Di Indonesia," Lex Jurnalica 6, no. 3 (2009): 185, https://ejurnal.esaunggul.ac.id/index. php/Lex/article/view/296.
} 
Settlement Dispute, namely between the article on dispute resolution by ODR and the article on dispute resolution in writing).

According to the author, there is disharmony or Inconsistency Norm (inconsistent legal norms) that occur in regulations relating to dispute resolution through non-litigation Online Dispute Resolution, namely between several articles in Law Number 30 of 1999 concerning Arbitration and Alternative Dispute Resolution, namely the existence of a discrepancy or contradiction between the applicable legal rules, so that the legal rules become vague and unclear. That is, according to several articles, namely Article 6 paragraph (2). Article 9 paragraph (1), Article 24 paragraph (5), Article 31 paragraph (1), Article 36 paragraph (1), Article 50 paragraph (3), Article 59 paragraph (2), and Article 63 of the AAPS Law state the settlement process Arbitration disputes are mandatory/must be in writing, while according to several articles, namely Article 4, Article 8 and Article 36 paragraph (2) of the AAPS Law, it can be done online.

Described as follows: Law Number 30 of 1999 concerning Arbitration and Alternative Dispute Resolution in Article 4 paragraph (3) In the event that it is agreed that dispute resolution through arbitration occurs in the form of an exchange of letters, the sending of telex, telegram, facsimile, e-mail or in the form of other means of communication, must be accompanied by a note of receipt by the parties, Article 8 paragraph (1) In the event of a dispute arising, the applicant must notify the respondent by registered letter, telegram, telex, facsimile, e-mail or with an expedition book to the respondent that the terms of arbitration held by the applicant or the respondent applies.

Article 36 paragraph (1): Examination of disputes in arbitration must be done in writing. Some of the articles that implied the settlement of the ODR dispute contradicted other articles which implied the settlement of disputes in writing. Article 9 paragraph (1) In the event that the parties choose to settle the dispute through arbitration after the dispute has occurred, the agreement regarding this matter must be made in a written agreement signed by the parties, Article 31 paragraph (1) The parties in a firm and written agreement, are free to determine the arbitration procedure used in the examination of disputes as long as they do not conflict with the provisions of this Law. And Article 36 paragraph (1) The examination of disputes in arbitration must be carried out in writing, and according to Article 6 paragraph (2) which states that dispute resolution is resolved in a direct meeting by the parties within a maximum period of 14 days and the results are stated in a written agreement. This article means that online Arbitration and Online Dispute Resolution so far have not been implemented in Indonesia because both Arbitration and APS require problems/ disputes to be resolved in a direct meeting by the parties and the physical presence of the parties before the Arbitration hearing, contrary to Article 4 which states dispute resolution can be through the internet.

It can be seen from the contents of the articles above, which according to several articles of Law Number 30 of 1999 concerning Arbitration and Alternative Dispute Resolution states that the Arbitration dispute resolution process can be online or 
through internet media, while other articles state that it can be through internet or online media, According to the researcher, this is a disharmony or Inconsistency Norm (inconsistent legal norms) that occurs in regulations relating to the settlement of commercial business disputes through non-litigation Online Dispute Resolution. According to the researcher, this makes the process of the non-litigation dispute resolution mechanism through the Online Dispute Resolution chaotic, due to disharmony or inconsistency of legal regulations, so that the legal rules become vague, vague and unclear which also makes the parties involved have no legal basis and later the process of resolving commercial business disputes through non-litigation Online Dispute Resolution will not be well directed.

To overcome this inconsistency, the government should make legal regulations that specifically regulate ODR or revise Law Number 30 of 1999 and add articles related to ODR. And immediately ratify the academic report on the Draft Government Regulation regarding the mechanism for resolving commercial business disputes through non-litigation online dispute resolution by adding rules on how to apply, costs, and technical implementation, to fill legal voids regarding online dispute resolution in order to provide legal certainty for the parties.

Table 1

The location of disharmony or inconsistency norms that occur in regulations relating to dispute resolution through non-litigation Online Dispute Resolution in Indonesia

Law Number 30 of 1999
concerning Arbitration and
Alternative Dispute Resolution,
which implicitly contains the
Online Dispute Resolution

Article 4

In the event that it is agreed that dispute resolution through arbitration occurs in the form of: exchange of letters, the sending of telex, telegram, facsimile, e-mail or in other forms of communication means, must be accompanied by a note of receipt by the parties.

\section{Article 8}

In the event of a dispute arising, the applicant must notify by registered letter, telegram, telex, facsimile, e-mail or by expedition book to the respondent that the terms of the arbitration held by the applicant or the respondent apply.

\section{Article 36}

2) Verbal examination may be carried out if agreed by the parties or deemed necessary by the arbitrator or arbitral tribunal.

Law Number 30 of 1999 concerning Arbitration and Alternative Dispute Resolution, which implicitly includes written dispute resolution

Article 6

(2) dispute resolution is resolved in a direct meeting by the parties within a maximum period of 14 days and the results are stated in a written agreement.

\section{Article 9}

(1) In the event that the parties choose to settle the dispute through arbitration after the dispute has occurred, an agreement regarding this matter must be made in a written agreement signed by the parties. 


\section{Article 24}

(5) A claim for denial must be submitted in writing, either to the other party or to the arbitrator concerned by stating the reasons for the claim.

Article 31

(1) The parties in a firm and written agreement are free to determine the arbitration procedure used in the examination of the dispute as long as it does not conflict with the provisions of this Law.

\section{Article 36}

(1) Examination of disputes in arbitration must be done in writing.

\section{Article 46}

(2) The parties are given the last opportunity to explain in writing their respective positions and submit evidence deemed necessary to strengthen their positions within the timeframe determined by the arbitrator or the arbitral tribunal.

(3) The arbitrator or arbitral tribunal has the right to ask the parties to submit additional written explanations, documents or other evidence deemed necessary within a period determined by the arbitrator or arbitral tribunal.

\section{Article 50}

(3) The arbitrator or arbitral tribunal shall forward a copy of the statement of the expert witness to the parties so that a written response can be made by the disputing parties.

\section{Article 59}

(2) The submission and registration as referred to in paragraph (1) shall be carried out by recording and signing at the end or at the edge of the decision by the Registrar of the District Court and the arbitrator or his proxies who submit, and the record is a registration deed.

Article 63

The order of the Chairman of the
District Court shall be written on the original sheet and an authentic copy of the arbitral award issued.

Source: self-made based on applicable laws and regulations

Based on the table above, according to the author, there is disharmony or Inconsistency Norm (inconsistent legal norms) that occur in regulations relating to dispute resolution through non-litigation Online Dispute Resolution / ODR (Online Dispute Resolution), namely between several articles in the Act Number 30 of 1999 concerning Arbitration and Alternative Dispute Resolution, namely the existence of a discrepancy or contradiction between the applicable legal rules, so that the legal rules become vague and unclear. That is, according to several articles, namely Article 6 paragraph (2). Article 9 paragraph (1), Article 24 paragraph (5), Article 31 paragraph (1), Article 36 paragraph (1), Article 50 paragraph (3), Article 59 paragraph (2), and Article 63 of the AAPS Law state the settlement process Arbitration disputes are mandatory/must be in writing, while according to several articles, namely Article 4, Article 8 and Article 36 paragraph (2) of the AAPS Law, it can be done online.

The following is the description: Law Number 30 of 1999 concerning Arbitration and Alternative Dispute Resolution in Article 4 paragraph (3) In the event that it is agreed that dispute resolution through arbitration occurs in the form of an exchange of letters, then the sending of telex, telegram, facsimile, e-mail or in the form of other means of communication, must be accompanied by a note of acceptance by 
the parties. Article 8 paragraph (1) In the event that a dispute arises, the applicant must notify by registered letter, telegram, telex, facsimile, e-mail or with an expedition book to the respondent that the conditions for arbitration held by the applicant or the respondent apply.

Article 36 paragraph (1): Examination of disputes in arbitration must be done in writing. Several articles which implied the settlement of the ODR dispute were contrary to other articles which implied the settlement of disputes in writing: Article 9 paragraph (1) In the event that the parties choose to settle the dispute through arbitration after the dispute has occurred, an agreement regarding this matter must be made in a written agreement signed by the parties, Article 31 paragraph (1) The parties in a firm and written agreement are free to determine the arbitration procedure used in the examination of the dispute as long as it does not conflict with the provisions of this Law. And Article 36 paragraph (1) The examination of disputes in arbitration must be carried out in writing, and according to Article 6 paragraph (2) which states that dispute resolution is resolved in a direct meeting by the parties within a maximum period of 14 days and the results are stated in a written agreement. This article means that online Arbitration and Online Dispute Resolution (ODR) have so far not been able to be applied in Indonesia because both Arbitration and APS require problems/disputes to be resolved in a direct meeting by the parties and the physical presence of the parties before the Arbitration hearing, contrary to Article 4 which states that dispute resolution can be through the internet.

From the contents of the ar- ticles above, which according to several articles of Law Number 30 of 1999 concerning Arbitration and Alternative Dispute Resolution states that the Arbitration dispute resolution process can be online or through internet media, while other articles state that it can be through internet media or online, this is According to the researcher, there is a disharmony or Inconsistency Norm that occurs in regulations relating to the settlement of commercial business disputes through non-litigation Online Dispute Resolution. According to the researcher, this makes the process of the non-litigation dispute resolution mechanism through the Online Dispute Resolution chaotic, due to disharmony or inconsistency of legal regulations, so that the legal rules become vague, vague and unclear which also makes the related parties do not have a strong legal basis and later the process of resolving commercial business disputes through non-litigation Online Dispute Resolution is not well directed.

DUE TO LEGAL UNCERTAINTY ABOUT THE MECHANISM FOR COMMERCIAL BUSINESS DISPUTE SETTLEMENT THROUGH NON LITIGATION ONLINE DISPUTE RESOLUTION IN INDONESIA

Prospects of Implementing Commercial Business Dispute Resolution Mechanisms through Non Litigation Online Dispute Resolution in Efforts to Settle Conventional Business Disputes and Ecommerce Transactions in Indonesia

The world of trade today has developed two main models of trade, namely the conventional business trading model and the 
modern trade model or what is called modern business. Internet technology is used as an innovative trading system that allows the transfer of information quickly to all corners of the world through cyberspace. Information is placed as a very important and profitable economic commodity. ${ }^{27}$ One aspect of economic activity that uses information technology is in terms of transacting using the internet, known as e-commerce. ${ }^{28}$

E-commerce is intended to eliminate difficulties in conventional business transactions so that dispute resolution through the judiciary is of course not expected to be carried out. In today's business world, dispute resolution through courts or dominant litigation is not of interest to many parties. $^{29}$ In the end, the settlement was carried out through the judiciary or litigation, this was merely a last resort (ultimatum remedium) after other attempts were unsuccessful. Looking at the current conditions, we need an appropriate, effective and efficient system. To answer this, the modern business world has turned to online dispute resolution as a modern dispute resolution because of the need for fast dispute resolution and low cost. ${ }^{30}$

Online dispute resolution provides an excellent solution in resolving trade disputes separated by geographical location, even between countries. The increase in

\footnotetext{
${ }^{27}$ Syamsiah Amali, "Utilization of the Internet for Students in the City of Gorontalo," Journal of Research and Communication of Public Opinion on the Dynamics of Law (2013): 14, https://kolomberbagi. files.wordpress.com/2011/10/pehasilan-internetpada-pelajar-di-kota-gorontalo.pdf.

28 Ibid.

29 Ibid, 11

30 Ibid.
}

the third wave of society which is characterized by interaction with information technology devices causes conventional trade to shift to a more modern system by combining law, economics, management and technology. The use of information technology in the dispute resolution system is very helpful for parties who are in cross-country so that it opens up new alternatives for justice seekers (justiciable) in resolving their disputes. ${ }^{31}$

Online dispute resolution in Indonesia is considered more "fast, simple, and lowcost" so that business people can resolve their disputes based on this principle. Online dispute resolution is also considered to balance the pace of development of the technology and information era, so that the application of online settlement is considered important in legal reform in Indonesia. $^{32}$

In the conventional dispute resolution system there are three parties involved, namely the disputing parties and a neutral third party, while the online dispute resolution system introduces a fourth party, namely the technology used by negotiators, mediators, and arbitrators in the dispute resolution process. ${ }^{33}$ Online dispute resolution is carried out by parties located in borderless areas or across geographies without having to meet face to face. Online dispute resolution has various methods, namely online negotiation, online mediation, and online arbitration. ${ }^{34}$

\footnotetext{
31. Ibid, 16

32 Ibid.

${ }^{33}$ Rifkin Janet Katsh, Online Dispute Resolution: Resolving Conflicts in Cyberspace (Bandung: Genta Publishing, 2011), 67

${ }^{34}$ Ibid.
} 
Online dispute resolution has been conceptualized in Indonesian legislation. This can be seen in the legislation that applies to positive law in Indonesia, namely, among others, Law Number 30 of 1999 concerning Arbitration and Alternative Dispute Resolution. ${ }^{35}$

The application of online dispute resolution in Indonesia requires several supporting factors to be implemented, one of which is the legal umbrella factor so that for the sake of legal certainty for the community and business people in particular, a "lex specialist" is needed for the prospect of implementing online dispute resolution. ${ }^{36}$ Indonesia's positive law has regulated and widely opened non-litigation dispute resolution through Law Number 30 of 1999 concerning Arbitration and Alternative Dispute Resolution which is the basis for implementing online dispute resolution in Indonesia using methods such as online negotiation, online mediation, and online arbitration. ${ }^{37}$

The method of dispute resolution outside the court provides an opportunity for the disputing parties to choose the best way to resolve the dispute. Online dispute resolution is basically included in the realm of contract law so that the principle of freedom of contract applies, meaning that the parties are free to make legal choices and the choice of dispute resolution forums that will be used in the event of a civil dispute. ${ }^{38}$ Article 1 Number (10) of Law

\footnotetext{
${ }^{35}$ Ibid, 96

36 Ibid.

${ }^{37}$ Moch Basarah, Alternative Procedures for Traditional and Modern (Online) Arbitration Dispute Resolutio (Jakarta: Genta Publishing, 2011), 112

38 Ibid.
}

Number 30 of 1999 concerning Arbitration and Alternative Dispute Resolution has encouraged methods of dispute resolution outside the court through technology and communication in accordance with the development of the era undergoing modernization so that geographical conditions are no longer a barrier at this time. ${ }^{39}$

Based on the provisions in Article 65 Paragraph (5), the disputing parties are given the freedom to choose their dispute resolution institution either through the courts or through other dispute resolution mechanisms. This is a driving factor for the implementation of an online dispute resolution institution in Indonesia. ${ }^{40}$

\section{Principles of Dispute Resolution Theory on the Implementation of Commercial Business Dispute Resolution through Non Litigation Online Dispute Resolu- tion in Indonesia}

When a dispute occurs, the dispute resolution carried out depends on how the dispute is managed. Dispute management in question is how the disputing parties deal with and try to resolve the dispute. "Theoretically there are two ways that can be taken in resolving disputes, namely adversarial or litigation (arbitration or court) and cooperatively (negotiation, mediation or conciliation). Settlement through litigation is bringing the dispute to court or arbitration while cooperative settlement is a cooperative effort in resolving disputes through direct negotiation, through the assistance of a mediator or through the as-

\footnotetext{
39 Ibid, 115

40 Ibid.
} 
sistance of a conciliator. ${ }^{41}$

. Normatively, arrangements regarding Arbitration and Alternative Dispute Resolution in Indonesia can be found in Law no. 30 of 1999. However, the legitimacy of the existence of online arbitration and the implementing rules governing how online arbitration is carried out are not clearly regulated in these regulations. ${ }^{42}$ If the arrangements for the implementation of online arbitration are left to the parties to arrange them themselves, it is feared that there are no standard standards regarding the effective and efficient implementation of online arbitration. In addition, there are also many obstacles, especially regarding the facilities and infrastructure for the implementation of online arbitration. ${ }^{43}$

The existence of ODR has actually offered a new concept in dispute resolution on the internet, but also provides several possibilities. Daewon Choi in his writing entitled Online Dispute Resolution: Issues and Future Directions expressed his opinion that: "Some of these possibilities include not only detemporalization and depersonalization but also dematerialization and deterritorialization of conflicts". ${ }^{44}$

From this statement ODR offers a very broad scope of dispute resolution or conflict. Forms of disputes that are very difficult to resolve through a settlement system

${ }^{41}$ Nurnaningsih Amriani, MEDIATION: Alternative Dispute Resolution in. Court (Jakarta: PT. King Grafindo Persada, 2012), 19

${ }^{42}$ Ibid, 21

43 Ibid.

${ }^{44}$ Daewon Choi, “Online Dispute Resolution: Issues and Future Direction," in Proceedings of the UNECE Forum (The National Center For Technology \& Dispute Resolution, 2003), 3, http://www.odr.info/ unece 2003. in the real world, through this ODR will be able to be resolved properly. The forms of disputes include data protection disputes, taxation in transactions, and defamation or violation of privacy. ${ }^{45}$ In reality, the ODR model has already begun to be practiced by several parties as evidenced by the presence of internet services that specifically provide services in terms of ODR. One thing that can be observed is that of a website from Australia known as www. adronline.com.au. In addition there are also other sites, namely www.squaretrade. com. $^{46}$

The principle of dispute resolution theory on the implementation or application of Non-Litigation Dispute Resolution through Online Dispute Resolution, namely where there is a mindset that directs the law to the dispute resolution process which will be a guide (leitstern) to achieve the wishes of the disputing parties. ${ }^{47}$ Where in this case there is a desire from the parties who will or are currently resolving disputes through non-litigation dispute resolution mechanisms through online dispute resolution, which have or want clear legal certainty regarding legal regulations regarding non-litigation dispute resolution mechanisms through Online Dispute Resolution so that later it can be resolved properly. ${ }^{48}$

Legal Consequences arising from the Disharmony of Legal Regulations regarding Mechanism of Settlement of Commercial Business Disputes through

\footnotetext{
${ }^{45}$ Ibid, 7

46 Ibid.

47 Ibid.

${ }^{48}$ Ibid.
} 


\section{Non Litigation Online Dispute Resolu- tion in Indonesia}

The disharmony of regulatory law means that there is a discrepancy, contradiction, incompatibility and incompatibility between the applicable legal rules, so that the legal rules become vague. ${ }^{49}$

This results in confusion among the public in understanding these regulations. This confusion in society results in the non-optimal legislation in solving a problem that occurs. Inconsistency can also affect the legal balance that lives in the midst of society because of the different interpretations of judges on inconsistent laws and regulations. ${ }^{50}$

In the author's opinion there is a disharmony or Inconsistency Norm that occurs in the regulations relating to Online Dispute Resolution, namely between several articles in Law Number 30 of 1999 concerning Arbitration and Alternative Dispute Resolution.

The importance of the role of written laws, namely as a source of national law for all citizens, is undeniably influenced by the legal system adopted by Indonesia. Indonesia is a country that adheres to the legal tradition of Continental Europe or often referred to as civil law, one of the characteristics of civil law is the importance of written legislation or statutory law or statutory legislation. The position of "statutory laws" takes precedence over judges decisions or jurisprudence. ${ }^{51}$

According to the author, this is due to

\footnotetext{
${ }^{49}$ Harjono, "Pengaruh Sistem Hukum Common Law Terhadap Hukum Investasi Dan Pembiayaan Di Indonesia."

50 Ibid,. 185

51 Ibid, 184
}

the lack of clarity and lack of firmness in regulating issues regarding ODR, causing many interpretations in explaining what is meant by ODR and how the mechanism or procedure for resolving non-litigation disputes through ODR is.

Several articles in Law Number 30 of 1999 concerning Arbitration and Alternative Dispute Resolution are contradictory and do not contain elements related to nonlitigation dispute resolution mechanisms through Online Dispute Resolution, so that the legal consequences are causing a blurring of norms and legal uncertainty.

According to the author, the legal consequences of disharmony or Inconsistency Norm occur in the regulations contained in several articles in Law Number 30 of 1999 concerning Arbitration and Alternative Dispute Resolution which are related and implicitly contain the settlement of commercial business disputes through non-litigation Online Dispute Resolution. This makes the process of the non-litigation dispute resolution mechanism through the Online Dispute Resolution chaotic, due to disharmony or inconsistency of legal regulations, so that the legal rules become vague, vague and unclear which also makes the parties involved do not have a strong legal basis. and later the process of resolving commercial business disputes through non-litigation Online Dispute Resolution becomes not well directed, this is a situation where the norm already exists but does not have a clear meaning or the norm gives rise to more than one meaning that makes the norm vague or not clear.

In the author's opinion, the existence of disharmony or Inconsistency Norm and the existence of legal uncertainty regard- 
ing Non-litigation ODR can be an obstacle in the application of ODR in Indonesia. In this all-digital era, lawmakers must always try to keep up with developments, especially in the field of information technology, considering that innovation and change occur very quickly and make it difficult for lawmakers to formulate and establish effective regulations because of the nature of the law relating to The technology actually has a short life span

\section{CONCLUSION}

The mechanism for resolving commercial business disputes through non-litigation Online Dispute Resolution is regulated in Law Number 30 of 1999 concerning Arbitration and Alternative Dispute Resolution. However, there is legal ambiguity in the law because it does not explain the mechanism for resolving commercial business disputes through non-litigation Online Dispute Resolution.

According to the author, there is disharmony or Inconsistency Norm that occurs in regulations relating to dispute resolution through non-litigation Online Dispute Resolution, namely between several articles in Law Number 30 of 1999 concerning Arbitration and Alternative Dispute Resolution, namely the existence of discrepancies or contradictions between the rules and regulations. the applicable law, so that the rule of law becomes vague and unclear. That is, according to several articles, namely Article 6 paragraph (2). Article 9 paragraph (1), Article 24 paragraph (5), Article 31 paragraph (1), Article 36 paragraph (1), Article 50 paragraph (3), Article 59 paragraph (2), and Article 63 of the AAPS Law state the settlement process Arbitration disputes are mandatory/must be in writing, while according to several articles, namely
Article 4, Article 8 and Article 36 paragraph (2) of the AAPS Law, it can be done online. According to the researcher, this makes the process of non-litigation dispute resolution mechanisms through Online Dispute Resolution not running well.

The legal consequences of the uncertainty of regulations which implicitly state about ODR in Law Number 30 of 1999 concerning Arbitration and Alternative Dispute Resolution, make the legal rules vague, vague and unclear which also makes the parties concerned do not have a strong legal basis and later the process of resolving commercial business disputes through non-litigation Online Dispute Resolution will not be well directed.

\section{Suggestion}

It is advisable for the government to make legal regulations that specifically regulate ODR or revise Law Number 30 of 1999 and add articles related to ODR. And immediately ratify the academic report on the Draft Government Regulation concerning the mechanism for resolving commercial business disputes through non-litigation online dispute resolution by adding rules on how to apply, costs, and technical implementation, to fill legal voids regarding online dispute resolution in order to provide legal certainty for the parties.

To the Government to provide websites and institutions that can specifically handle dispute resolution through non-litigation online dispute resolution to handle commercial business dispute resolution. It is also necessary to improve the quality of internet and telecommunication network infrastructure as well as competent experts in language and technology, in order to bring Indonesia to be 
more prepared in resolving disputes, especially online business disputes.

\section{BIBLIOGRAPHY}

\section{Books}

Amriani, Nurnaningsih. MEDIATION: Alternative Dispute Resolution in. Court. Jakarta: PT. King Grafindo Persada, 2012. Barkatullah, Abdul Halim. Perlindungan Hukum Bagi Konsumen Dalam Transaksi E-Commerce Lintas Negara Di Indonesia. Yogyakarta: FH UII Press, 2009.

Basarah, Moch. Alternative Procedures for Traditional and Modern (Online) Arbitration Dispute Resolutio. Jakarta: Genta Publishing, 2011.

Katsh, Rifkin Janet. Online Dispute Resolution: Resolving Conflict in Cyberspace. Bandung: Genta Publishing, 2016.

- Online Dispute Resolution: Resolving Conflicts in Cyberspace. Bandung: Genta Publishing, 2011.

Nasional, Pusat Bahasa Departemen Pendidikan. Kamus Bahasa Indonesia. Jakarta: Departemen Pendidikan Nasional, 2008.

Riswandi, Budi Agus. Hukum Cyberspace. Yogyakarta: Gita Nagari, 2006.

Siburian, Paustinus. Arbitrase Online: Alternatif Penyelesaian Sengketa Perdagangan Secara Elektronik. Jakarta: Djambatan, 2004.

Suparman, Eman. Pilihan Forum Arbitrase Dalam Sengketa Komersial Untuk Penegakan Keadilan. Jakarta: Tatanusa, 2004.

\section{Journal}

Amali, Syamsiah. "Utilization of the Internet for Students in the City of Gorontalo." Journal of Research and Communication of Public Opinion on the Dynamics of Law (2013): 14. https://kolomberbagi. files.wordpress.com/2011/10/pehasilaninternet-pada-pelajar-di-kota-gorontalo. pdf.

Candra, Adel. "Penyelesaian Sengketa Transaksi Elektronik Melalui Online Dispute Resolution (ODR) Kaitan Dengan UU Informasi Dan Transaksi Elektronik." Jurnal Ilmu Komputer 10, no. 2 (n.d.): 8089. https://digilib.esaunggul.ac.id/public/ UEU-Journal-3653-adel-chandra.pdf.

Harjono, Dhaniswara K. "Pengaruh Sistem Hukum Common Law Terhadap Hukum Investasi Dan Pembiayaan Di Indonesia." Lex Jurnalica 6, no. 3 (2009): 185. https:// ejurnal.esaunggul.ac.id/index.php/Lex/ article/view/296.

Utama, Gagah Satria. "Online Dispute Resolution: A Revolution in Modern Law Practice." Business Law Review 1, no. 3 (2017): 5. https://law.uii.ac.id/wpcontent/uploads/2017/04/V-01-No-03online-dispute-resolution-a-revolution-inmodern-law-practice-gagah-satria-utama. pdf.

\section{Internet}

Choi, Daewon. "Online Dispute Resolution: Issues and Future Direction." In Proceedings of the UNECE Forum, 3. The National Center For Technology \& Dispute Resolution, 2003. http://www.odr. info/unece2003.

Hill, Richard, and Ian Walden. "Electronic Commerce Can Be Defined as Commercial Activities Conducted through an Exchange of Information Generated, Stored, or Communicated by Electronical, Optical or Analogues Means, Including EDI, E-Mail, and so Forth" The Draft UNCITRAL Model Law for ." Last modified 1996. 
http://openstorage.gunadarma.ac.id/idkf/ idkf/aplikasi/hukum-dan-warfare/mastelregulasi-2B.doc14.

Nureda, Kania Rahma. "Penyelesaian Sengketa Secara Online Di Indonesia." Hukum Online. Last modified 2017. Accessed November 22, 2020. https:// www.hukumonline.com/berita/baca/ 1t593793b7764b1/penyelesaian-sengketasecara-online-di-indonesia-oleh--kaniarahma-nureda.

Oktavira, Bernadheta Aurelia. "Perbedaan Mediator, Arbiter, Dan Konsiliator." Hukum Online. Last modified 2019. Accessed November 22, 2020. https:// www.hukumonline.com/klinik/detail/ ulasan/1t 5 dd 65 ff 35 fc $6 \mathrm{f} /$ perbedaanmediator--arbiter--dan-konsiliator/.

"MA Memiliki Sisa Perkara Sebanyak 9.306." Mahkamah Agung Republik Indonesia. Accessed February 11, 2021. https://www. mahkamahagung.go.id/.

"Mengenal Litigasi: Mengenai Penyelesaian Sengketa Di Meja Hijau." DSLA. Accessed February 19, 2021. https://www. dslalawfirm.com/id/litigasi/.

\section{Law and Regulation}

Law Number 30 of 1999 concerning Arbitration and Alternative Dispute Resolution

The 1945 Constitution of the Republic of Indonesia 